Птиця Н.В., Ковцур К.Г.

Харківський національний автомобільно-дорожній університет

\title{
КРИТЕРІЙ ДОЦІЛЬНОСТІ ВВЕДЕННЯ ОБ’ЄКТІВ ТОРГІВЕЛЬНОЇ МЕРЕЖІ НА ОСНОВІ ПАРАМЕТРІВ СИСТЕМИ ДОСТАВКИ
}

\footnotetext{
Розглядаються особливості доставки вантажів у роздрібну торгівельну мережу. В роботі наведене обгрунтування критерію введення нових об'єктів торгівельної мережі, який представляє собою частку витрат на транспортування в доходній частині. Використання запропонованого критерію дозволить оцінити ефективність розширення торгівельної мережі. Визначено вплив параметрів системи доставки вантажів на критерій ефективності.

Ключові слова: роздрібна торгівельна мережа, доставка, логістичні витрати, щільність торгівельних точок, витрати на транспортування, кількість пунктів заїзду на маршруті.
}

Постановка проблеми. Високі практичні вимоги до якості організації доставки вантажів у роздрібну торгівельну мережу визначають необхідність ретельного планування процесу доставки. Жорсткі часові обмеження на транспортування, невеликі партії вантажу є суттєвими перешкодами для використання автомобілів більшої вантажопід'ємності, а також проектування маршрутів за критерієм мінімум сумарного пробігу. В сучасних умовах вирішити цю оптимізаційну задачу без використання економіко-математичних методів не представляється можливим.

Аналіз останніх досліджень. Транспортування $є$ ключовою логістичною функцією, це обумовлено великою часткою витрат на їх виконання (60\% від загальних логістичних витрат) [1]. Без транспортування практично не існує матеріального потоку. При цьому процес транспортування розглядається у більш широкому плані, ніж перевезення вантажів: як сукупність перевезень, навантаження та розвантаження, експедитування та ін. Суттєвий вплив витрати на транспортування здійснюють і на дохід в цілому (рис. 1) [2].

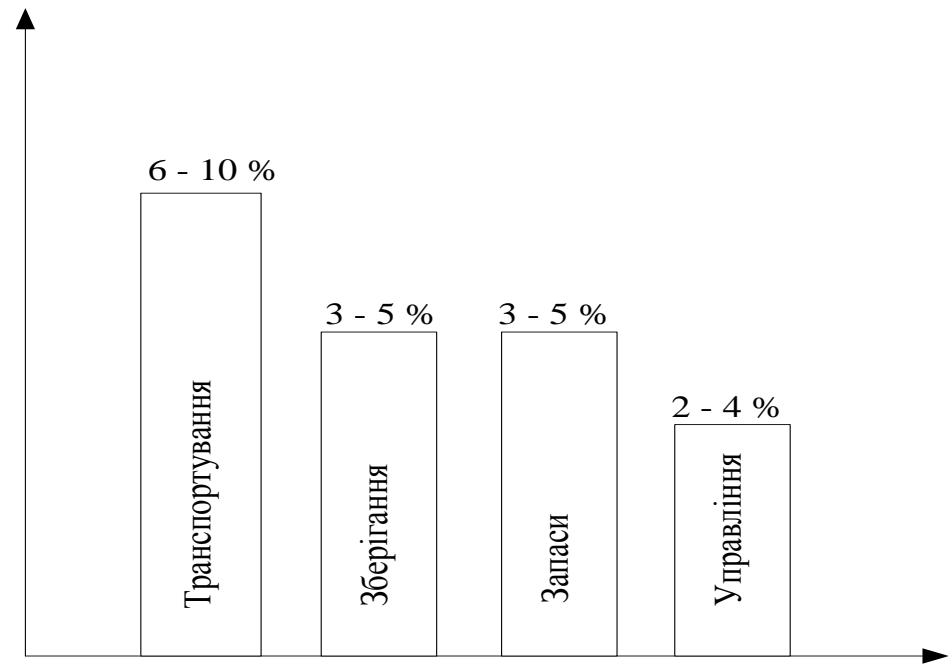

Рисунок 1 - Структура логістичних витрат у відсотках від доходу

В роздрібній торгівлі широко розповсюджені дрібнопартійні перевезення $[1,3,4,5,6,7,8]$. Це пов'язано з тим, що роздрібні мережі включають в себе торгівельні точки різних форматів, з великим асортиментним рядом продукції. Особливістю продовольчих товарів $\epsilon$ щодобове їх завезення. Розмір партії, що завозиться, визначається розміром споживання за певний період $\mathrm{i}$, як правило, не забезпечує повного завантаження навіть автомобілів малої вантажопід’ємності. В таких умовах доцільне використання розвізних маршрутів, так як використання маятникових призведе до суттєвого збільшення витрат на доставку $[1,3,6]$.

В $[2,3,6,9,10]$ з метою отримання конкурентних переваг в роздрібній торгівлі та мінімізації витрат на транспортування пропонується спрямовувати зусилля на управління перевізниками, обгрунтованого вибору виду транспорту та оптимізацію масштабів всієї мережі. При правильному 
підході можливість економії може сягати від 5 до $15 \%$ від загальної суми витрат. В [9] вказується, що операційні витрати, пов'язані з транспортуванням вантажів можна знизити за рахунок оптимізації кількості, розміру та місць розташування пунктів доставки, виробничих потужностей та парку транспортних засобів.

Доставка вантажів у роздрібну торгівельну мережу (РТМ) характеризується територіальним розосередженням торгівельних точок, що визначає розсіювання вантажопотоку [10, 5]. Нерівномірність перевезень погіршує використання провізних спроможностей транспортних засобів. Виправити ситуацію можна використовуючи комплексний підхід до планування перевезень, визначення оптимальної кількості пунктів завозу та їх раціонального розміщення.

Важливість оптимізації транспортної ланки розглядається і в $[5,6,11,12,13]$, де наголошується, що чітко налагоджена маршрутизація та визначення оптимальної кількості пунктів заїзду і максимальне використання вантажності транспортного засобу дозволить знизити витрати на доставку.

В [14] автор визначає важливі параметри роздрібної мережі, які впливають на формування матеріального потоку в логістичній системі, серед яких особлива увага приділяється кількості учасників торгівельних точок, а також особливості технологічних аспектів доставки.

Автор в [15] характеризує залежність витрат кожного виду від кількості елементів інфраструктури і в підсумку визначає такий вигляд даної залежності (рис. 2).

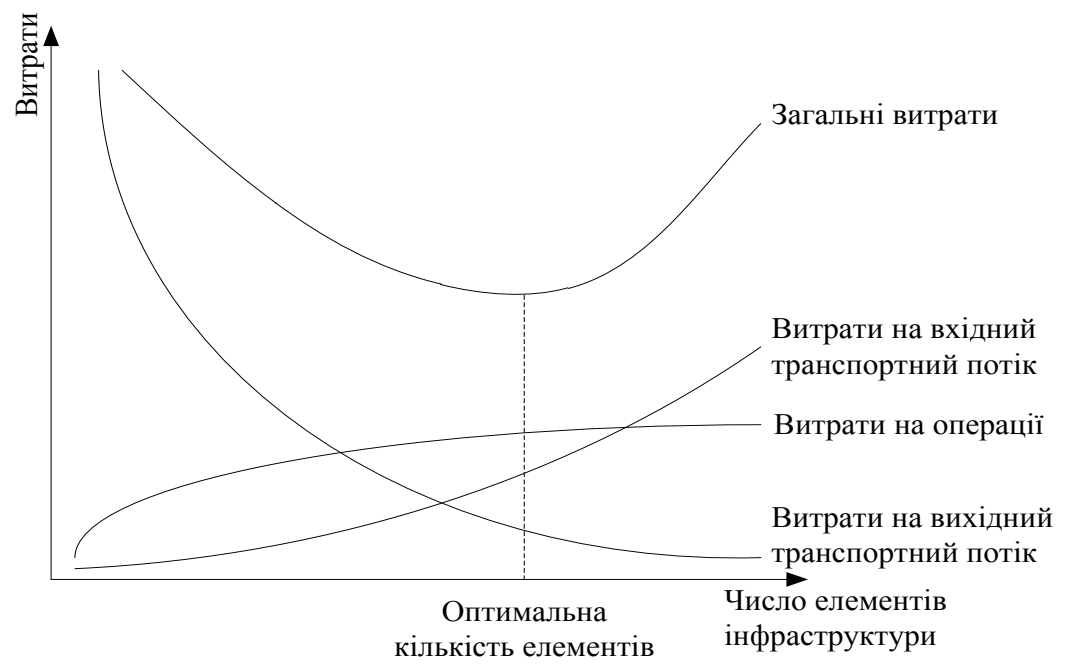

Рисунок 2 - Залежність кількості елеметів інфраструктури від логістичних витрат на транспортування

Невелика кількість елементів забезпечує низькі транспортні витрати на вхідний, але високі витрати на вихідний потік. Велика ж кількість елементів демонструє зворотню залежність. У загальних витрат є чіткий мінімум, відповідно оптимальній кількості елементів в системі.

Міротін Л.Б. в [16] пропонує для визначення кількості об'єктів логістичної системи розглядати графічний метод розв'язання даної задачі. Пропонується в розрізі всієї системи розподілу оцінити, як в залежності від зміни кількості об'єктів змінюються ті чи інші витрати. Зміну кількості об'єкті в логістичній системі роздрібної торгівельної мережі можна охарактеризувати показником щільність торгівельних точок.

В роботі [11] представлено математичну модель оптимальної довжини ланцюга постачань на основі критерію загальних приведених витрат на доставку. Запропоновано уявлення ізольованого ланцюга постачань за допомогою обліку зовнішніх зв'язків проміжних ланок у вигляді показника ступеня концентрації матеріалопотоку. Довжина ланцюга постачань $\epsilon$ безперервною функцією і в роботі апроксимована ступеневою функцією, в якій значущими параметрами $\epsilon$ площа території обслуговування, обсяг партії, який завозиться кожному отримувачу, кількість споживачів продукції, ціна одиниці продукції, коефіцієнт використання вантажопідйомності, відносне змішання постачальника від центру тяжіння території обслуговування.

Формулювання цілей роботи. Всіма вищезгаданими авторами визнається суттєва зміна загальних витрат на транспортування вантажів у зв'язку з появою нового об'єкту в системі доставки, але не приводиться чіткий алгоритм для оцінки цієї зміни. Таким чином виникає задача визначення 
частки витрат на транспортування продукції від доходу мережі при введенні нового об'єкту в залежності від щільності торгових точок.

Основна частина. При розширенні мережі, місце розміщення обирається 3 огляду на максимальне наближення до споживачів. В таких умовах до логістики повинні пред’являтися жорсткі вимоги, щоб високі логістичні витрати не поглинули значну частку доходу від розширення. Більшість підприємств націлює свої логістичні системи на максимізацію прибутку. Теоретично зона обслуговування кожної торгової точки встановлюється за критерієм мінімально допустимого прибутку від доставки вантажів на різну відстань. Оскільки нові торгові точки зазвичай розміщують в територіально різно-віддалених місцях для збільшення ринкової частки, то виникає необхідність визначення вартості логістичних послуг з доставки вантажів. Віддаленість нових торгових об'єктів, при якій витрати по транспортному обслуговуванню приносять мінімально прийнятний прибуток, визначає граничну відстань і подальше розширення зони обслуговування понад цієї відстані $\epsilon$ неприбутковим.

Управління ланцюгом постачань призначене для здійснення особливого внеску у генерування доходу та прибутку. Оцінювання фінансових показників дає змогу організації ефективно проаналізувати окремі види діяльності і, тим самим, визначити, як саме ланцюг постачань впливає на кожну складову підсумкового прибутку.

Головна ціль функціонування роздрібної торгівельної мережі це максимізація прибутку, що можна представити наступним чином

$$
D-B \rightarrow \max
$$

де $D$ - дохід, грн;

$B$ - витрати, грн.

Як частина логістичної системи роздрібної мережі автомобільний транспорт повинен мати спільну ціль і, відповідно, критерії оцінки ефективності його функціонування повинні узгоджуватись.

Критерії оцінки ефективності роботи автомобільного транспорту поділяються на дві групи [10]: натуральні та вартісні. Натуральні критерії (кількість транспортних засобів, матеріаломісткість, продуктивність автомобіля, час доставки вантажу та ін.) привабливі простотою математичних задач, однак при виборі критерію неминуче виникнення конфліктної ситуації протиріччя.

Найбільш об'єктивними є вартісні критерії, які більш точно та повно відображають поняття ефективності транспортного процесу [12, 17]. Найбільш поширені 3 них: доходи від перевезень, витрати, прибуток, собівартість та рентабельність. Використання питомих показників від валових дозволить співвідносити ефективність роботи окремого підрозділу з об' ємом отримуваних доходів.

3 огляду на це у загальному випадку співвідношення витрат на транспортування з доходами дає змогу оцінити їх частку, з метою подальшої їі мінімізації

$$
\delta=\frac{B}{D} \cdot 100 \rightarrow \min
$$

Можливість оцінити не лише вагу витрат вже існуючих торгівельних точок роздрібної мережі, але й розрахувати частку для нового об’єкту та отримати оптимальне їх співвідношення формує цільову наступну функцію дослідження

$$
\delta=\frac{B_{m p}}{D_{i}+D_{j}} \cdot 100 \rightarrow \min
$$

де $B_{m p}$ - витрати на транспортування вантажів у нову торгівельну точку, грн.;

$D_{i-}^{-}$загальний дохід існуючої РТМ, грн;

$D_{j}$ - очікуваний дохід від нової точки РТМ, грн.

Запропонована цільова функція має наступні обмеження:

$$
\left\{\begin{array}{l}
n_{3} \geq 1 ; \\
Q_{i}=\sum_{i=1}^{n_{3}} g_{i} \\
\sum_{j=1}^{M} n_{3}=N_{T T} \\
q_{\max }=10
\end{array}\right.
$$


де $n_{3}$ - кількість пунктів заїзду на маршруті, од.

$Q_{i}$ - розмір замовлення на маршруті, т;

$g_{i}$ - середній розмір замовлення в одній торгівельній точці, т;

$M$ - кількість маршрутів, од;

$N_{T T}$ - кількість торгових точок в районі обслуговування, од.

$q_{\max }$ - максимально допустима вантажність автомобіля, т.

Зменшення частки витрат на транспортування можна досягти шляхом корегування кількості пунктів заїзду на маршруті при можливості збільшення партії відправок, шляхом підвищення коефіціенту використання вантажності автомобіля в результаті проведення маршрутизації, тобто при розробці раціональних розвізних маршрутів з урахуванням щільності торгівельних точок мережі.

3 урахуванням наведеної системи обмежень, витрати на доставку вантажу в логістичній системі РТМ можна представити як:

$$
B_{m p}=S_{m p} \cdot M
$$

де $S_{m p}$ - витрати на транспортування вантажу на одному маршруті, грн/т;

$M$ - кількість маршрутів, необхідних для організації доставки товарів у всі точки РТМ, од.

Витрати на транспортування вантажу на одному маршруті враховують постійні та змінні складові та розраховуються за формулою

$$
S_{m p}=C_{3 м} \cdot l_{o б}+C_{n o c m} \cdot t_{o \sigma} \cdot
$$

де $C_{\text {зм }}, C_{\text {nост }}$ - змінна і постійна складові витрат на перевезення, які визначаються відповідно

$$
\left\{\begin{array}{l}
C_{3 . м}=A_{3 . м}+B_{3 м} \cdot q_{H} \\
C_{\text {nocm }}=A_{\text {nocm }}+B_{\text {nocm }} \cdot q_{H},
\end{array}\right.
$$

де $A_{3, \mu}, B_{3 м}, A_{n о с m}, B_{\text {пост }}{ }^{-}$коефіцієнти регресійної моделі залежності собівартості автомобільних перевезень від вантажопідйомності автомобіля, грн/км, грн/год., грн/т · км та грн/т·год відповідно.

Довжина оберту на маршруті, $l_{\text {об }}$, км, розраховується за формулою

$$
l_{\text {об }}=2 l_{i}+\left(n_{3}-1\right) \cdot l_{(i-1)-i},
$$

де $l_{(i-1)-i}$ - відстань між суміжними пунктами заїзду на маршруті, км;

$l$ - середня відстань доставки, яку можна представити наступним чином

$$
l_{i}=\frac{2}{3} R_{c p},
$$

де $R_{c p}$ - середній радіус території обслуговування, км².;

$$
R_{c p}=\sqrt{\frac{\lambda^{-1}}{\pi}}
$$

В роботах багатьох дослідників за основу приймається, що район обслуговування має форму кола. Виходячи з даного припущення, середній пробіг автомобілів між суміжними пунктами заїзду на маршруті складе

$$
l_{(i-1)-i}=0,76 \sqrt{\lambda^{-1}},
$$


де $\lambda$ - щільність торгівельних точок у регіоні, од./км².;

Необхідний показник щільності можна визначити, виходячи з площі регіону $\left(F_{M}\right)$

$$
\lambda=\frac{N_{T T}}{F_{M}} .
$$

де $F_{\mu}$ - загальна площа території обслуговування (міста), км²;

$N_{T T}$ - кількість торгівельних точок мережі, од.

Час оберту на маршруті визначається

$$
t_{o \sigma}=\frac{l_{o \sigma}}{V_{m}}+t_{H / p}+\left(n_{3}-1\right) \cdot t_{\partial} .
$$

де $t_{\partial}$ - додатковий час на оформлення документів, год;

$V_{m}$ - технічна швидкість автомобіля, км/год;

Час на навантаження-розвантаження визначається за наступною залежністю

$$
t_{H / p}=2 \cdot\left(t_{\partial}+q_{H} \cdot \gamma_{c m} \cdot \tau_{H / p}\right),
$$

де $q_{H}$ - номінальна вантажність автомобіля, т.

$\tau_{H-p}$ - витрати часу на навантаження або розвантаження вантажу, год/т;

$\gamma_{c m}$ - коефіцієнт статичного використання вантажності.

Номінальна вантажність автомобіля визначається за формулою

$$
q_{H}=\frac{n_{3} \cdot \bar{g}}{\gamma_{c m}}
$$

де $n_{3}$ - номінальна кількість пунктів заїзду на маршруті, од.

Оптимальна кількість пунктів заїзду на розвізних маршрутах має наступний вид

$$
n_{3}=\sqrt{\frac{A_{\text {зм }} \cdot \gamma_{\text {ст }} \cdot\left[2 \cdot l_{i}-l_{(i-1)-i}\right]}{B_{3 \mathrm{M}} \cdot \bar{g} \cdot l_{(i-1)-i}}},
$$

де $\bar{g}$ - середній обсяг замовлень, т.

$$
\bar{g}=\frac{Q_{\mu} \cdot \delta_{M}}{N_{T T} \cdot 365},
$$

де $Q_{м}$ - обсяг товарообігу споживчих товарів у регіоні, грн./ т.;

$\delta_{\mu}$ - частка товарообігу окремої мережі, \%.

Обсяг товарообігу розраховується виходячи із співвідношення товарообігу регіону та вартості однієї тони споживчих товарів, та має наступний вид

$$
Q_{M}=\frac{T_{M}}{L_{T}},
$$

де $T_{\mu}$ - вартість товарообігу споживчих товарів у регіоні, грн./ т.;

$Ц_{T}$ - вартість 1-ї тони споживчих товарів, грн.

Частка товарообігу окремої мережі визначається за залежністю $[18,19]$

$$
\delta_{M}=\frac{r_{n}}{r_{n}+R_{c p}^{m}}
$$


де $r_{n}$ - радіус половинного попиту мережі, км.;

$R_{c p}^{m}$ - середній радіус обслуговування торгівельної точки, км.

Радіус половинного попиту визначається залежністю $[19,20]$

$$
r_{n}=\frac{\bigsqcup_{c p} \cdot R_{c p}^{m}}{Ц_{2 p}+\bigsqcup_{i}},
$$

де $\bigsqcup_{c p}$ - вартість середнього чеку на ринку, грн.;

$\bigsqcup_{z p}$ - гранична ціна споживчого товару, грн.;

$Ц_{i}$ - вартість середнього чеку окремої мережі, грн.

Дохід торгівельної мережі визначається

$$
D_{i}=N_{T T} \cdot Ц_{T} \cdot \bar{g},
$$

Дохід нової торгівельної точки можна визначити за залежністю

$$
D_{j}=T_{\mu} \frac{r_{n}}{r_{n}+R_{c p}^{m}},
$$

Підставивши вирази (5-22) у вираз (3) маємо

$$
\begin{aligned}
& \delta=\frac{\left(A_{3 M}+B_{3 M} \cdot q_{H}\right) \cdot\left[\frac{4 \cdot \sqrt{\frac{1}{\lambda}}}{3 \cdot \sqrt{\pi}}+0,76 \cdot \sqrt{\frac{1}{\lambda}} \cdot\left(n_{3}-1\right)\right]+}{n_{3} \cdot\left(\frac{T_{M} \cdot r_{\Pi}}{r_{\Pi}+\frac{\sqrt{\frac{1}{\lambda}}}{\sqrt{\pi}}}+\frac{T_{M} \cdot r_{\Pi}}{365 \cdot r_{\Pi}+\frac{365 \cdot \sqrt{\frac{1}{\lambda}}}{\sqrt{\pi}}}\right)} \\
& +\left(A_{\text {nocm }}+B_{\text {nocm }} \cdot q_{H}\right) \cdot\left[2 \cdot t_{\partial}+t_{\partial}\left(n_{3}-1\right)+\frac{\frac{4 \cdot \sqrt{\frac{1}{\lambda}}}{3 \cdot \sqrt{\pi}}+0,76 \cdot \sqrt{\frac{1}{\lambda}} \cdot\left(n_{3}-1\right)}{V_{T}}+2 \cdot q_{u} \cdot \gamma_{c m} \cdot \tau_{\text {up }}\right]
\end{aligned}
$$

Аналіз моделі частки витрат на транспортування дозволив визначити змінні та постійні фактори, що імовірно впливають на ефективність системи доставки вантажів у роздрібну торгівельну мережу. Змінними величинами є: щільність дислокації торгових точок $(\lambda$, од/км² $)$, доля товарообігу мережі $\left(\delta_{m}, \%\right)$, вартість товарообігу споживчих товарів у регіоні, $\left(T_{m}\right.$, грн./т.), вартість середнього чеку на ринку $\left(L_{c p}\right.$, грн.), середній радіус обслуговування у регіоні $\left(R_{c p}\right.$, км.), коефіцієнт використання вантажності $\left(\gamma_{c m}\right)$. Постійні фактори: технічна швидкість автомобіля $\left(V_{m}\right.$, км/год), норма витрат часу на навантаження/розвантаження $\left(\tau_{\mu p}\right.$, т/год), додатковий час на оформлення документів $\left(t_{\partial}\right.$, год), коефіціснти регресійної моделі залежності собівартості автомобільних перевезень від вантажності автомобіля.

Висновки. В результаті проведеного дослідження сформульована цільова функція розрахунку частки витрат роздрібної торгівельної мережі з урахуванням щільності торгівельних точок. За допомогою отриманої математичної моделі обрані змінні та постійні фактори, які впливають на іiі ефективність. Наступним кроком дослідження стане проведення повнофакторного експерименту типу $2^{\mathrm{K}}, 3$ метою отримання закономірностей впливу параметрів доставки на частку витрат на транспортування. Використання запропонованого підходу визначення частки транспортних витрат в дохідній частини торгівельної мережі дозволить встановити доцільність введення нових об'єктів та подальше ії розширення. 
1. Афанасьев Л.Л., Цукерберг С.М. Автомобильные перевозки. - М.: Транспорт, 1973. - 320 с.

2. Гатторна Дж. Управление цепями поставок: Справочник издательства Gower / пер. с англ. изд. - М.:ИНФРА-М, 2008. $-670 \mathrm{c}$.

3. Ковалев К.Ю. Логистика в розничной торговле: как построить эффективную сеть / К.Ю. Ковалев, С.А. Уваров, П.Е. Щеглов. - СПб.: Питер, 2007. - 272 с.

4. Шаповал Д.В. Совершенствование оперативного планирования перевозок мелкопартионных грузов автомобилями на радиальных маршрутах в городах: дис. ... кандидата техн. наук: 05.22.10 / Шаповал Дмитрий Владимирович. - Омск, 2012. - $138 \mathrm{c}$.

5. Сидоров Д. Розничные сети. Секреты эффективности и типичные ошибки при работе с ними / - М.: Вершина, 2007. $-230 \mathrm{c}$.

6. Миргородский М.А. Повышение эффективности перевозок грузов мелкими отправками : дис. . кандидата техн. наук : 05.22.10 / Миргородский Михаил Александрович. - Орел, 2010. - 151 с.

7. Леви М. Основы розничной торговли / М. Леви, Б. Вейтц. - Спб.: Питер, 2001.- 448 с.

8. Ковцур Е.Г. Резервирование провозных возможностей парка автомобилей при доставке товаров в супермаркеты / Е.Г. Ковцур // Восточно-Европ. журнал передовых технологий, 2012. - Вып. 1/3(55). - С. 54-57.

9. Аникин Б.А. Аутсорсинг: создание высокоэффективных и конкурентоспособных организаций. /Аникин Б.А./ М.: Инфра-М, 2003. - 192 с.

10. Уотерс Д. Логистика. Управление цепью поставок: пер. с англ. - М.: ЮНИТИ-ДАНА, 2003. - 503 с.

11. Потаман Н.В. Выбор рационального количества складов в цепочке поставок продукции автомобильным транспортом в межрегиональном сообщении: Дис... канд. техн. наук: 05.22 .01 - Транспортные системы / Харьковский национальный автомобильно-дорожный университет. - Харьков, 2010. - 243 с.

12. Доля В.К. О сравнительной эффективности технологий доставки грузов / В.К. Доля, Н.А. Нефедов// Проблемы развития автомобильного транспорта и подготовки кадров. - 1996. - Харьков: Основа. - с. 16-18.

13. Нефьодов М.А. Визначення структури парку автомобілів для перевезень продовольчих товарів народного споживання / М.А.Нефьодов, К.Г. Ковцур // Вестник Харьковского национального автомобильно-дорожного университета. - Х:, 2009. - Вып. 47. - С. 127-130.

14. Рославцев Д.М. Вплив параметрів роздрібної мережі на формування матеріальних потоків в логістичній системі в умовах міста / Комунальне господарство міст / - № 67. 2005. - с. 310-312.

15. Лукинский В.С. Логистика автомобильного транспорта: концепция, методы, модели / В.С. Лукинский, В.И. Бережной, Е.В. Бережная и др. - М.: Финансы и статистика, 2002. - 280с.

16. Транспортная логистика / Под ред. Л.Б. Миротина. - М.: Транспорт, 1996. - 211с.

17. R. Ballou, Business Logistics Management. - New York: Prentise Hall. - 478 p.

18. Н.А. Нефедов. Маркетинговые аспекты логистики // Вестник Харьковского государственного автомобильнодорожного технического университета - Вып. 8, 1999. - С. 70 - 72.

19. Птица Н.В. Оптимальный радиус обслуживания клиентуры // Сборник научных трудов VII Всероссийской конференции студентов и аспирантов «Проблемы и перспективы развития логистики и управления цепями поставок» (23-24 апреля). - Москва: Изд. Дом Высшей школы экономики, 2013.

20. Птица Н.В. Влияние рационализации параметров логистической сети на развитие розничной торговли в Украине // Вестник экономики транспорта и промышленности. Сборник научно-практических статей - Вып. 46 - Харьков 2014 . - с. 204-207.

\section{REFERENCES}

1. Afanas'yev L.L., Tsukerberg S.M. (1973). Avtomobil'nyye perevozki, 320.

2. Gattorna Dzh. (2008) Upravleniye tsepyami postavok: Spravochnik izdatel'stva Gower,. 670.

3. Kovalev K.YU., Uvarov S.A., (2007). Logistika v roznichnoy torgovle: kak postroit' effektivnuyu set', 272 .

4. Shapoval D.V. (2012). Sovershenstvovaniye operativnogo planirovaniya perevozok melkopartionnykh gruzov avtomobilyami na radial'nykh marshrutakh v gorodakh. Candidate's thesis, 138.

5. Sidorov D. (2007). Roznichnyye seti. Sekrety effektivnosti i tipichnyye oshibki pri rabote s nimi 230.

6. Mirgorodskiy M.A. (2010). Povysheniye effektivnosti perevozok gruzov melkimi otpravkami. Candidate's thesis, 151.

7. Levi M. (2001). Osnovy roznichnoy torgovli, 448.

8. Kovtsur Ye.G. (2012). Rezervirovaniye provoznykh vozmozhnostey parka avtomobiley pri dostavke tovarov v supermarkety, 54-57.

9. Anikin B.A. (2003). Autsorsing: sozdaniye vysokoeffektivnykh i konkurentosposobnykh organizatsiy, 192.

10. Uoters D. (2003). Logistika. Upravleniye tsep'yu postavok: per. s angl, 503 p.

11. Potaman N.V.(2010). Vyibor ratsionalnogo kolichestva skladov $\mathrm{v}$ tsepochke postavok produktsii avtomobilnyim transportom v mezhregionalnom soobschenii: Candidate's thesis, 243.

12. Dolya V.K., Nefedov N.A. (1996). O sravnitel'noy effektivnosti tekhnologiy dostavki gruzov, 16-18.

13. . Nef'odov M.A., Kovtsur K.H (2009). Vyznachennya struktury parku avtomobiliv dlya perevezen' prodovol'chykh tovariv narodnoho spozhyvannya, 127-130.

14. Roslavtsev D.M. (2005). Vplyv parametriv rozdribnoyi merezhi na formuvannya material'nykh potokiv v lohistychniy systemi v umovakh mista, 310-312.

15. Lukinskiy V.S., Berezhnoy V.I., Berezhnaya Ye.V (2002). Logistika avtomobil'nogo transporta: kontseptsiya, metody, modeli, 280.

16. Mirotin L.B (1996). Transportnaya logistika, 211.

17. R. Ballou, Business Logistics Management, 478 p.

18. Nefedov. N.A. (1999). Marketingovyye aspekty logistiki $70-72$.

19. Ptitsa N.V. (2013). Optimal'nyy radius obsluzhivaniya kliyentury.

20. Ptitsa N.V. (2014) Vliyaniye ratsionalizatsii parametrov logisticheskoy seti na razvitiye roznichnoy torgovli v Ukraine. 204-207 p. 
Птица Н.В., Ковцур Е.Г. Критерий целесообразности введения объектов торговой сети на основе параметров системы доставки

Рассматриваются особенности доставки грузов в розничную торговую сеть. В работе приведено обоснование критерия введения новых объектов торговой сети, представляющий собой долю затрат на транспортировку в доходной части. Использование предложенного критерия позволит оценить эффективность расширения торговой сети. Определена зависимость параметров системы доставки грузов на критерий эффективности.

Ключевые слова: розничная торговая сеть, доставка, логистические затраты, плотность торговых точек, расходы на транспортировку, количество пунктов заезда на маршруте.

Ptytsia N.V., Kovtsur E.G. The expediency criterion of introduction of the trade network objects based on the delivery system parameters

The features of the delivery of goods to the retail network is presented. In paper the substantiation of the criterion of introduction of new trade network objects, representing a share of delivery expenses to revenues. Using the proposed criterion will evaluate the effectiveness of expanding the trade network. The dependence of the parameters of the cargo delivery system on the criterion of efficiency is defined. in the route

Key words: retail trade network, delivery logistics costs, the density of retail outlets, transportation costs, number of points-

\section{АВТОРИ:}

ПТИЦЯ Наталія Василівна, аспірант кафедри транспортних систем і логістики, Харківський національний автомобільно-дорожній університет, e-mail: nataliya.ptitsa@gmail.com.

КОВЦУР Катерина Григорівна, кандидат технічних наук, доцент кафедри транспортних систем i логістики, Харківський національний автомобільно-дорожній університет, e-mail: kovtsyr@ukr.net.

\section{АВТОРЫ:}

ПТИЦА Наталья Васильевна, аспирант кафедры транспортных систем и логистики, Харьковский национальный автомобильно-дорожный университет, e-mail: nataliya.ptitsa@gmail.com.

КОВЦУР Екатерина Григорьевна, кандидат технических наук, доцент кафедры транспортных систем и логистики, Харьковский национальный автомобильно-дорожный университет, e-mail: kovtsyr@ukr.net.

\section{AUTHORS:}

PTYTSIA Natalia Vasylivna, Postgraduate student of Transport Systems and Logistics Department, Kharkiv National Automobile and Highway University, e-mail: nataliya.ptitsa@gmail.com.

KOVTSYR Kateryna Grigorivna, Candidate of Technical Sciences, Associate Professor of Transport Systems and Logistics Department, Kharkiv National Automobile and Highway University, e-mail: kovtsyr@ukr.net. 